\title{
Intake, apparent digestibility, and methane emission in bulls receiving a feed supplement of monensin, virginiamycin, or a combination
}

\author{
Marcelina Pereira da Fonseca ${ }^{\mathrm{A}}$, Ana Luiza da Costa Cruz Borges ${ }^{\mathrm{A}, \mathrm{D}}$, Ricardo Reis e Silva ${ }^{\mathrm{A}}$, \\ Helena Ferreira Lage ${ }^{\mathrm{A}}$, Alexandre Lima Ferreira ${ }^{\mathrm{A}}$, Fernando César Ferraz Lopes ${ }^{\mathrm{B}}$, \\ Carlos Giovani Pancoti ${ }^{\mathrm{A}}$ and José Avelino Santos Rodrigues ${ }^{\mathrm{C}}$ \\ AFederal University of Minas Gerais, Veterinary School, Antônio Carlos Av, 6627, PO Box 567, 30161-970, Belo \\ Horizonte, MG, Brazil. \\ ${ }^{B}$ Brazilian Company of Agricultural Research, Eugenio do Nascimento Street 610 - Don Bosco, 36038-330, Juiz de \\ Fora, MG, Brazil. \\ ${ }^{\mathrm{C}}$ Brazilian Company of Agricultural Research - Corn and Sorghum, PO Box 285, 35701-970, Sete Lagoas, MG, \\ Brazil. \\ ${ }^{\mathrm{D}}$ Corresponding author. Email: analuizavetufmg@gmail.com
}

\begin{abstract}
The aim of this study was to evaluate the effects of the feed supplements monensin, virginiamycin, or a combination of the two, on intake, digestibility, and methane emission in the male cattle breed $F_{1}$ Holstein $\times$ Gir. We used a complete randomised design with four treatments consisting of the control, monensin, virginiamycin, and a combination of the two. The basal diets were composed of sorghum silage with Tanzania grass and the concentrate in the $1: 1$ ratio. Nutrient intake $(P>0.05)$ and the apparent digestibility coefficients $(P>0.05)$ were not affected by the supplementation with monensin, virginiamycin, or both. The combination of the supplements did affect methane emission $(P<0.05)$ when expressed in L/day, $\mathrm{L} /(\mathrm{kg} \mathrm{DM})$, and $\mathrm{L} /(\mathrm{kg} \mathrm{DM}$ digestible). The lowest methane production was obtained with the combination of the supplements.
\end{abstract}

Additional keywords: additives, cattle, feed supplement, greenhouse gas, respirometric chamber.

Received 6 August 2014, accepted 11 November 2014, published online 26 February 2015

\section{Introduction}

Energy is considered a limiting factor in living organisms because it affects the vital functions. Therefore, in addition to determining energy levels in food, assessing the efficiency of feed utilisation is of fundamental importance for attainment of optimised nutritional requirements (Cabral et al. 2006).

For some time, many studies have been focussed on improving energy efficiency in cattle by means of ionophoric antibiotics, such as monensin, to manipulate ruminal fermentation processes. According to Bergen and Bates (1984), monensin acts selectively on ruminal microbial populations, causing changes in the end products of fermentation. Little is known, however, about the effect of monensin on in vivo methane production by cattle living under tropical conditions. Virginiamycin is a non-ionophoric antibiotic produced by a mutant strain of Streptomyces virginiae; this medication is composed of the factors $\mathrm{M} \quad\left(\mathrm{C}_{28} \mathrm{H}_{35} \mathrm{~N}_{3} \mathrm{O}_{7}\right)$ and $\mathrm{S}$ $\left(\mathrm{C}_{43} \mathrm{H}_{49} \mathrm{~N}_{7} \mathrm{O}_{10}\right)$, which have a synergistic effect when combined at the $4: 1$ ratio, respectively. The activity of this antibiotic takes place within the bacterial cell, where both factors bind specifically and irreversibly to the $50 \mathrm{~S}$ subunit of ribosomes, inhibiting peptide bond formation during protein synthesis (Cocito 1979). The combined use of virginiamycin and monensin has not been studied well.

Therefore, our objective was to assess the effects of dietary supplementation with monensin, virginiamycin, or a combination of these, on intake, digestibility, and methane production of $\mathrm{F}_{1}$ bulls (Holstein $\times$ Gir) as determined by respirometric-chamber analysis.

\section{Materials and methods \\ The location of the study}

The procedures in this study were approved by the Committee of Ethics and Animal Experimentation of the Federal University of Minas Gerais (protocol \#215/10). The experiment was conducted at the Laboratory of Animal Metabolism and Calorimetry, Department of Animal Science, Veterinary School of the Federal University of Minas Gerais, from 25 October 2011 to 10 January 2012. The climate of the region is of the CWA type (dry winter and rainy summer) with a local altitude of $841 \mathrm{~m}$ above sea level (Muller 1982). 
The cattle breed and housing facilities

We used $20 \mathrm{~F}_{1}$ (Holstein $\times$ Gir) bulls at initial average age of 8 months and initial average liveweight of $150.0 \mathrm{~kg}$. Before any experimental procedures, the animals remained free in the experimental corral and were trained to familiarise themselves with the facilities and management. Subsequently, the animals underwent an identification process, were vaccinated against clostridial diseases, and treated for a possible endoparasite infection with levamizol and ivermectina and for a possible ectoparasite infection with fipronil. Finally, the animals received $5 \mathrm{~mL}$ of the $\mathrm{ADE}$ injectable vitamin supplement containing 2500000 IU of retinol, 500000 IU of calciferol, and $1650 \mathrm{IU}$ of tocopherol via intramuscular injection. The animals were kept in a feedlot arranged according to the 'Tie stall' system. A feeder and drinking fountain were provided individually. In order to ensure greater comfort, each stall was equipped with pallets of rubber Vedovati $1.10 \mathrm{~m}$ long, $0.90 \mathrm{~m}$ wide, and $0.1 \mathrm{~m}$ thick. The daily floor cleaning procedures consisted of removal of faeces and urine followed by thorough mopping.

\section{Diet and experimental management}

The experimental diets, formulated according to the recommendations of the NRC (2000), were isonitrogenous and isocaloric and were designed to meet the requirements of $0.5 \mathrm{~kg}$ of daily gain. The roughage consisted of sorghum silage [Sorghum bicolor (L.)] with Tanzania grass (Panicum maximum Jacq cv. Tanzânia). The concentrates consisted of corn, soybean meal, urea, common salt, and mineral core. Except for the control treatment, the concentrates were added to feed along with monensin and/or virginiamycin. The animals were adapted to the experimental diets for 21 days. The forage: concentrate ratio was $1: 1$ on a DM basis and remained fixed throughout the experimental period. Diets were supplied twice daily at 0900 hours and 1700 hours. Immediately before a meal, the forage was mixed with the concentrate to ensure the consumption of the complete diet and to avoid any feed selection by the animals. Daily and immediately before the morning meal, the orts were collected and weighed to determine the food intake of animals. To ensure ad libitum intake and to maintain orts at $\sim 10-20 \%$, daily adjustments were made to the provided quantities of feed. The chemical composition of the silage and the concentrates used in the experimental diets is shown in Table 1. Chemical composition of the experimental diets is shown in Table 2.

Table 1. Chemical composition of the concentrates and silage $\mathrm{C}$, control; $\mathrm{M}$, monensin; VM, virginiamycin; $\mathrm{M}+\mathrm{VM}$, monensin with virginiamycin

\begin{tabular}{lrrrrc}
\hline Nutrient & \multicolumn{5}{c}{ Concentrate } \\
(g/kg DM) & \multicolumn{1}{c}{$\mathrm{C}$} & \multicolumn{1}{c}{$\mathrm{M}$} & $\mathrm{VM}$ & $\mathrm{M}+\mathrm{VM}$ & Silage \\
\hline Dry matter & 864.8 & 868.1 & 863.9 & 864.9 & 268.7 \\
Organic matter & 946.8 & 934.2 & 942.0 & 938.6 & 940.1 \\
Mineral matter & 53.2 & 65.8 & 58.0 & 61.4 & 59.90 \\
Crude protein & 215.0 & 203.9 & 210.1 & 213.5 & 115.0 \\
Neutral detergent fibre & 160.8 & 140.2 & 162.0 & 176.2 & 616.0 \\
\hline
\end{tabular}

Monensin and/or virginiamycin were added to the concentrate formulated for the experiment: Rumensin 100 (concentration $10 \%$ ) manufactured by Elanco (Greenfield, IN, USA) and Eskalin (concentration 2\%) manufactured by Phibro (Ridgefield Park, NJ, USA). Monensin and/or virginiamycin were added at the doses of $22 \mathrm{mg} / \mathrm{kg} \mathrm{DM}$ and $30 \mathrm{mg} / \mathrm{kg} \mathrm{DM}$, respectively. Nucleus 160 (Alvorada Co. Rations, Maravilhas, Minas Gerais, Brazil) served as the source of mineral core.

\section{The apparent digestibility assay}

After the animals were adapted to the diets, we performed the apparent digestibility assay. To determine the total excreted faecal DM, a 5-day total faecal collection was performed in accordance with the methodology described by Ferreira et al. (2009). To quantify faecal DM, faecal material was collected in identified boxes, weighed, and sampled twice daily, once before each meal (at $\sim 0800$ hours and 1600 hours). A second set of faecal samples was also collected for determination of chemical composition.

The orts were collected, weighed, and sampled daily each morning, immediately before the first meal. The diets were sampled daily after each meal. All freshly sampled material (average $400 \mathrm{~g}$ ) was stored in plastic bags, identified, and frozen for subsequent chemical analyses.

\section{Methane emission}

During the pre-experimental period, the animals were placed inside the respirometric chamber to familiarise them with the chamber in order to minimise excess stress during experimental measurements and to assess behaviour of the animals within the chamber.

After the apparent digestibility assay, we initiated measurements of methane production in the respirometric chamber. The measurements started after 26 days of the experiment ( 21 days of diet adaptation and 5 days for the digestibility assay). Each animal was individually analysed by $\sim 22 \mathrm{~h}$, and the measurements were made for 20 days. The measurements were performed only in a chamber. The respirometric chamber was made of steel and acrylic side windows, $3.45 \mathrm{~m}$ long, $1.45 \mathrm{~m}$ wide, and $2.45 \mathrm{~m}$ high (22.391 $\mathrm{L}$ of internal volume). The measurements were performed according to the system of the open circuit, adopted by the Veterinary School, UFMG, according to Rodríguez et al. (2007) as described by Silva (2011). In this system, the air inside the chamber is continuously renewed by the constant

Table 2. Chemical composition of the experimental diets $\mathrm{C}$, control; $\mathrm{M}$, monensin; VM, virginiamycin; $\mathrm{M}+\mathrm{VM}$, monensin with virginiamycin; DM, dry matter; $\mathrm{OM}$, organic matter; $\mathrm{MM}$, mineral matter; $\mathrm{CP}$, crude protein; NDF, neutral detergent fibre; NFC, non-fibrous carbohydrates; EE, ether extract

\begin{tabular}{lccccccc}
\hline Diet & \multicolumn{7}{c}{ Nutrient (g/kg DM) } \\
& DM & OM & MM & CP & NDF & NFC $^{\mathrm{A}}$ & EE \\
\hline C & 566.7 & 943.5 & 56.5 & 165.0 & 388.4 & 369.2 & 20.8 \\
M & 568.3 & 937.6 & 62.4 & 159.5 & 378.1 & 378.0 & 21.5 \\
VM & 566.2 & 941.1 & 58.9 & 162.5 & 389.0 & 367.4 & 22.0 \\
M + VM & 566.8 & 939.4 & 60.6 & 164.2 & 396.1 & 364.4 & 22.2 \\
\hline
\end{tabular}

${ }^{\mathrm{A}} \mathrm{NFC}$ calculated according to Sniffen et al. (1992). 
entry of external air. A pump located outside the respirometric chamber performs the renewal of air by negative pressure. A sample of gas is redirected to the gas analysers, and then the gas sample is analysed for oxygen, carbon dioxide, and methane concentrations during $5 \mathrm{~min}$. Using the software provided by Sable Systems (Las Vegas, NV, USA), the amount of methane produced by an animal was calculated using the difference between the concentrations of the gas present in the external air and the air that leaves the chamber. After all measurements were performed, the orts of the food from each animal were collected, weighed, and sampled. The foods provided were also sampled daily; thus, at the end of the experiment, a composite sample of the diets provided during the measurements could be composed. The feed intake of animals during this period was also monitored: animals with aggressive behaviour or lower-thanexpected DM intake were evaluated again in the chamber.

\section{Sample preparation and laboratory analyses}

The feed, orts, and faeces samples were removed from the freezer, thawed at room temperature, and dried in a forced-air oven at $55 \pm 5^{\circ} \mathrm{C}$ to quantify pre-dried matter. Once pre-dried the samples were ground in a stationary mill (Thomas-Wiley model 4) equipped with a 5-mm-mesh sieve to form the composite samples. To quantify the faecal DM in the excreta, the collected faeces samples from each animal were pre-dried individually and were made into composites. The amount of a sample used for preparation of the composites was proportional to the excreted amounts of pre-dried matter. At the end of the assay, for each animal, we obtained a composite sample representative of the entire collection period.

The same procedure was followed for ort and food samples. The orts collected in the respirometric chamber were pre-dried and analysed individually. The composite samples were milled in the Thomas-Wiley model 4 mill, equipped with a 1-mm-mesh sieve, then stored in plastic jars with lids, and labelled according to the ID number of each animal, just as the individual samples were. Bromatological analysis was performed at the Laboratory of Animal Nutrition of the Veterinary School, UFMG. After predrying a sample in a forced-air oven at $55 \pm 5^{\circ} \mathrm{C}$, we assessed the contents of $\mathrm{DM}$ at $105^{\circ} \mathrm{C}$. The feed provided, orts, and faeces were analysed for crude protein $[\mathrm{CP}$; the procedure outlined in the Kjeldahl method described by Silva and Queiroz (2006)], ash [the gravimetric procedure described by Silva and Queiroz (2006)], and ether extract [the procedure described by Silva and Queiroz (2006)]. The neutral detergent fibre (NDF) content of the feed provided, orts, and faeces samples was determined according to the methodology proposed by Van Soest et al. (1991) in an ANKOM Fibre Analyser apparatus, using $5 \times 5-\mathrm{cm}$ bags made of tissue non-tissue, at the density of $100 \mathrm{~g} / \mathrm{m}^{2}$. The samples of the food concentrate were analysed in a beaker and crucible filter using the same neutral detergent solution and amylase, in quantities of $100 \mathrm{~mL}$ and $1 \mathrm{~mL}$ per sample, respectively, according to the method described by Silva and Queiroz (2006) and the modification proposed by Valente et al. (2011). The apparent digestibility coefficients were calculated by subtracting the amount excreted with faeces from the amount consumed, according to the method of Coelho da Silva and Leão (1979).

\section{Statistical analyses}

The experiment was conducted using a completely randomised design with four treatments, 20 experimental units, and five replicates per treatment. The statistical model was $\mathrm{Y}_{\mathrm{ij}}=\mathrm{M}+$ $\mathrm{G}_{\mathrm{i}}+\mathrm{e}_{\mathrm{ij}}$, where $\mathrm{M}$ is the overall mean, $\mathrm{G}_{\mathrm{i}}$ is the effect of treatment, and $\mathrm{e}_{\mathrm{ij}}$ is the aleatory error associated with the observations. The variables under study were subjected to ANOVA, and the means were compared using the Tukey test in the statistical software SAEG (2001) - Statistical Analysis System, version 8.0 , at $\alpha=0.05$.

\section{Results and Discussion}

The intakes of DM, organic matter (OM), NDF, and CP were not affected $(P>0.05)$ by the supplementation of the diets with monensin and/or virginiamycin. In this study, DM intake was unaffected by addition of the supplements to the diets. The forage : concentrate ratio was the same for all treatments, which may have contributed to the similar DM intake levels among treatments. Although the rate of passage was not determined in this study, it is possible that this metric was also unchanged. Similar results were obtained by Oliveira et al. (2005) in their evaluation of the addition of 14,28 , and $42 \mathrm{mg} / \mathrm{kg} \mathrm{DM}$ of monensin to the diet of Holstein heifers. Those authors did not find any differences $(P>0.05)$ in DM intake (expressed as $\mathrm{kg} /$ day and relative to the metabolic weight) and in OM and NDF intake levels, regardless of the levels of monensin. In contrast, Restle et al. (2001) reported a reduction in DM intake in heifers and cows fed with $650 \mathrm{~g} / \mathrm{kg}$ of sorghum silage and $350 \mathrm{~g} / \mathrm{kg}$ of concentrate containing $150 \mathrm{mg}$ of monensin per cow per day. At present, there are almost no data on the effect of virginiamycin on food intake of cattle, particularly under tropical conditions. Nuñez (2008) did, however, report lower DM intake and metabolisable energy in Nelore cattle receiving virginiamycin in combination with salinomycin at doses of 15 and $13 \mathrm{mg} / \mathrm{kg}$ $\mathrm{DM}$, respectively. He attributed the decrease in DM intake to the increased efficiency of utilisation of metabolisable energy. The author, however, used high-concentrate diets.

Updated committee recommendations for beef cattle feed (NRC 2000) were drafted according to databases on animals handled in feedlots. According to that document, monensin typically decreases food intake. Steers maintained under feed conditions consisting of $900 \mathrm{~g} / \mathrm{kg}$ concentrate supplemented with $31 \mathrm{mg} / \mathrm{kg}$ DM monensin, showed a $4 \%$ decrease in food intake. In the present study, the addition of monensin $(22 \mathrm{mg} / \mathrm{kg}$ $\mathrm{DM})$ to feed did not reduce DM intake $(P>0.05)$. It should be noted that the diets used in the literature cited by the above committee contain higher proportions of the concentrate compared with our work. The effects of high-energy diets are enhanced by ionophores that increase the levels of propionate and gluconeogenic precursors and decrease methane production (Nagaraja and Taylor 1987). In a comprehensive review of 48 studies on the use of growth promoters in beef cattle consuming forage-based diets, Bretschneider et al. (2008) concluded that ionophores, in a dose-dependent manner, primarily affect the average daily weight gain and feed conversions, with little or no effect on DM intake.

In our work, the coefficients of apparent digestibility of the DM, OM, CP, and NDF were not affected $(P>0.05)$ by 
addition of the supplements to the diets. Similarly, Eifert et al. (2005) did not detect any effects of monensin and/or soybean oil on the coefficients of apparent digestibility of the DM, OM, CP, and NDF in cows that received diets with $550 \mathrm{~g} / \mathrm{kg}$ of corn silage and $450 \mathrm{~g} / \mathrm{kg}$ of the concentrate. Likewise, Borges et al. (2008), in a similar experiment, tested the effects of the ionophoric antibiotic monensin and the nonionophoric antibiotic enramycin in diets containing $400 \mathrm{mg} / \mathrm{kg}$ of sugarcane and $600 \mathrm{mg} / \mathrm{kg}$ of the concentrate in bovine females. These authors did not find any difference in the coefficients of apparent digestibility of the DM, CP, and starch or in the coefficient of digestibility of the NDF.

Apparent digestibility is a parameter relevant to the assessment of quality of a diet because this metric shows the fraction of nutrients lost in the form of faeces. It is estimated that $\sim 30 \%$ of the energy consumed is excreted with faeces (Miller and Wolin 2001). In the present work, there are no changes in digestibility coefficients.

Furthermore, Chen and Wolin (1979) reported that the use of ionophores, particularly monensin, increases the populations of Selenomonas, Succinomonas, Megasphaera, and Veillonella and inhibits the growth of acetate-producing bacteria, such as Ruminococcus and Butyrivibrio. Simultaneously, higher concentrations of nicotinamide adenine dinucleotide (NADH/ $\mathrm{NAD}^{+}$) favour the synthesis of propionate via reoxidation of $\mathrm{NADH}$ and by limiting $\mathrm{H}_{2}$ and production of acetate. Fumarate reductase, an enzyme that converts fumarate to succinate, which in turn will be used to generate propionate, is found in monensinresistant Gram-negative bacteria (Bergen and Bates 1984). The effect of virginiamycin on Gram-positive bacteria also appears consistent (Nagaraja et al. 1997). In this case, there should be sensitivity to a drop in $\mathrm{pH}$, as suggested by Blaxter and Clapperton (1965); however, a drop in $\mathrm{pH}$ does not appear to be a consistent

Table 3. Mean values, probabilities ( $P$-value) and coefficients of variation $(\mathrm{CV})$ of the methane emission

Values followed by different letters in rows differ by Tukey test $P<0.05$. C, control; $\mathrm{M}$, monensin; VM, virginiamycin; $\mathrm{M}+\mathrm{VM}$, monensin with virginiamycin

\begin{tabular}{lcccccc}
\hline Item $^{\mathrm{A}}$ & \multicolumn{4}{c}{ Treatment } & \multicolumn{4}{c}{$P$-value CV (\%) } \\
& $\mathrm{C}$ & $\mathrm{M}$ & $\mathrm{VM}$ & $\mathrm{M}+\mathrm{VM}$ & \\
\hline (L/day) & $185.62 \mathrm{a}$ & $153.78 \mathrm{ab}$ & $171.57 \mathrm{ab}$ & $137.70 \mathrm{~b}$ & 0.0298 & 14.6 \\
(L/kg DM) & $28.86 \mathrm{a}$ & $24.97 \mathrm{ab}$ & $27.94 \mathrm{ab}$ & $23.27 \mathrm{~b}$ & 0.0342 & 11.4 \\
(L/kg DM dig.) & $48.21 \mathrm{a}$ & $41.63 \mathrm{ab}$ & $45.15 \mathrm{ab}$ & $38.84 \mathrm{~b}$ & 0.0484 & 11.6 \\
(L/kg NDF) & 68.81 & 58.01 & 63.75 & 57.27 & 0.2926 & 16.7 \\
(L/kg NDF dig.) & 163.78 & 140.56 & 135.10 & 147.75 & 0.2853 & 28.8 \\
(L/kg OM) & 31.36 & 25.74 & 30.89 & 26.94 & 0.1520 & 15.4 \\
(L/kg OM dig.) & 51.70 & 42.62 & 49.93 & 45.07 & 0.2909 & 17.0 \\
(L/kg LW ${ }^{0,75}$ ) & 3.19 & 2.53 & 2.95 & 2.42 & 0.0548 & 16.3 \\
(L/kg gain) & 120.66 & 107.25 & 127.18 & 108.24 & 0.2016 & 14.2 \\
\hline
\end{tabular}

${ }^{\mathrm{A}}$ Methane emission in litres by day (L/day), litres by kilogram of DM (L/kg $\mathrm{DM}$ ), litres by kilogram of DM digestible (L/kg DM dig.), litres by kilogram of neutral detergent fibre (L/kg NDF), litres by kilogram of NDF digestible ( $\mathrm{L} / \mathrm{kg}$ NDF dig.), litres by kilogram of organic matter ( $\mathrm{L} / \mathrm{kg} \mathrm{OM})$, litres by kilogram of OM digestible (L/kg OM dig.), litres by kilogram of liveweight metabolic $\left(\mathrm{L} / \mathrm{kg} \mathrm{LW}^{0,75}\right)$ and litres by kilogram of gain of weight (L/kg gain). effect in our work because reductions in feed intake or impaired digestibility of fibre were not observed.

Methane emission was lower $(P<0.05)$ in the animals receiving monensin in combination with virginiamycin, expressed in $\mathrm{L} / \mathrm{day}, \mathrm{L} /(\mathrm{kg} \mathrm{DM})$, and $\mathrm{L} /(\mathrm{kg}$ digestible $\mathrm{DM}$; Table 3). A reduction in methane production under the influence of the combination of monensin and virginiamycin makes sense given the consistent trend in the results expressed in daily amounts (L/day) or the results that are adjusted for feed intake. The ability of virginiamycin to increase net energy of diets was reported for cattle (Rogers et al. 1995; Nuñez 2008; Salinas-Chavira et al. 2009). The present report seems to be the first to demonstrate quantification of methane production in cattle receiving a supplement of monensin and/or virginiamycin under tropical conditions in a respirometric chamber.

\section{Conclusion}

Feed supplementation with monensin [22 mg/(kg DM)] and/ or virginiamycin $[30 \mathrm{mg} /(\mathrm{kg} \mathrm{DM})]$ does not alter feed intake or apparent digestibility coefficients in the total tract of bulls fed with diets containing the same ratio of roughage to the concentrate (with silage sorghum plus Tanzania grass as the sole source of roughage). The combination of monensin and virginiamycin at the above doses decreases emission of methane by cattle.

\section{Acknowledgements}

The authors are thankful for the research collaboration between the Universidade Federal de Minas Gerais, CNPq, FAPEMIG, EMBRAPA 'Corn and Sorghum' and INCT-Animal Science, which made this study possible. This research was funded by the Universidade Federal de Minas Gerais, Pro-rectory of Research (PRPq) of the UFMG, Belo Horizonte, MG, Brazil.

\section{References}

Bergen WG, Bates DB (1984) Ionophores: their effect on production, efficiency and mode of action. Journal of Animal Science 58, 1465-1483.

Blaxter KL, Clapperton JL (1965) Prediction of the amount of methane produced by ruminants. The British Journal of Nutrition 19, 511-522. doi:10.1079/BJN19650046

Borges LFO, Passini R, Meyer PM, Rodrigues PHM (2008) Efeitos da enramicina e monensina sódica sobre a digestão de nutrientes em bovinos alimentados com dietas contendo alto nível de concentrados. Revista Brasileira de Zootecnia 37, 674-680.

Bretschneider G, Elizalde JC, Pérez FA (2008) The effect of feeding antibiotic growth promoters on the performance of beef cattle consuming forage-based diets: a review. Livestock Science 114, 135-149. doi:10.1016/j.livsci.2007.12.017

Cabral LS, Valadares Filho SC, Detmann E, Malafaia PAM, Zervoudakis JT, Souza AL, Veloso RG, Nunes PMM (2006) Consumo e digestibilidade dos nutrientes em bovinos alimentados com dietas à base de volumosos tropicais. Revista Brasileira de Zootecnia 35, 2406-2412. doi:10.1590/ S1516-35982006000800029

Chen MJ, Wolin M (1979) Effect of monensin and lasalocid-sodium on the growth of methanogenic and rumen saccharolytic bacteria. Applied and Environmental Microbiology 38, 72-77.

Cocito C (1979) Antibiotics of the virginiamycin family, inhibitors which contain synergistic components. Microbiological Reviews 43, 145-198.

Coelho da Silva JF, Leão MI (1979) 'Fundamentos de nutrição dos ruminantes.' (Universidade de São Paulo: SP, Brazil)

Eifert EC, Lana RP, Leão MI, Arcuri PB, Valadares Filho SC, Leopoldino WM, Oliveira JS, Sampaio CB (2005) Efeito da combinação de óleo de 
soja e monensina na dieta sobre o consumo de matéria seca e a digestão em vacas lactantes. Revista Brasileira de Zootecnia 34, 297-308. doi:10. 1590/S1516-35982005000100034

Ferreira MA, Valadares Filho SC, Marcondes MI, Paixão ML, Paulino MF, Valadares RFD (2009) Avaliação de indicadores em estudos com ruminantes: digestibilidade. Revista Brasileira de Zootecnia 38, 1568-1573. doi:10.1590/S1516-35982009000800022

Miller TL, Wolin MJ (2001) Inhibition of growth of methane producing bacteria of the ruminant forestomach by hydroxymethylglutaryl-ScoA reductase inhibitors. Journal of Dairy Science 84, 1445-1448. doi:10. 3168/jds.S0022-0302(01)70177-4

Muller PB (1982) 'Bioclimatologia aplicada aos animais domésticos.' 2nd edn. (Embrapa Amazônia Ocidental: Porto Alegre, RS, Brazil)

Nagaraja TG, Taylor MB (1987) Susceptibility and resistance of ruminal bacteria to antimicrobial feed additives. Applied and Environmental Microbiology 53, 1620-1625.

Nagaraja TG, Newbold CJ, Van Nevel CJ, Demeyer DI (1997) Manipulation of rumenal fermentation. In 'Rumen microbial ecosystem'. 2nd edn. (Eds PN Hobson, CS Stewart) pp. 523-632. (Blackie Academic and Professional: London)

NRC (2000) 'Nutrient requirements of beef cattle.' 7th rev. edn. (National Academy Press: Washington, DC)

Nuñez AJC (2008) Uso combinado de ionóforo e virginiamicina em novilhos Nelore confinados com dietas de alto concentrado. MSc Dissertação, Universidade de São Paulo, SP, Brazil.

Oliveira MVM, Lana RP, Freitas AWP, Eifert EC, Pereira JC, Valadares Filho SC, Pérez JRO (2005) Parâmetros rumenal, sanguíneo e urinário e digestibilidade de nutrientes em novilhas leiteiras recebendo diferentes níveis de monensina. Revista Brasileira de Zootecnia 34, 2143-2154. doi:10.1590/S1516-35982005000600040

Restle J, Neumann M, Filho ADC (2001) Terminação em confinamento de vacas e novilhas sob dietas com ou sem monensina sódica. Revista Brasileira de Zootecnia 30, 1801-1812. doi:10.1590/S1516-3598200100 0700018
Rodríguez NM, Campos WE, Lachica ML, Borges I, Gonçalves LC, Borges ALCC, Saliba EOS (2007) A calorimetry system for metabolism trials. Arquivo Brasileiro de Medicina Veterinária e Zootecnia 59, 495-500. doi:10.1590/S0102-09352007000200033

Rogers JA, Branine ME, Miller CR, Wray MI, Bartle SJ, Preston RL, Gill DR, Pritchard RH, Stilborn RP, Bechtol DT (1995) Effects of dietary virginiamycin on performance and liver abscess incidence in feedlot cattle. Journal of Animal Science 73, 9-20.

SAEG (2001) ‘Sistema para análises estatísticas. Versão 8.0.' (SAEG: Viçosa, $\mathrm{MG})$

Salinas-Chavira LJ, Ponce E, Sanchez U, Torrentera N, Zinn RA (2009) Comparative effects of virginiamycin supplementation on characteristics of growth-performance, dietary energetics, and digestion of calf-fed Holstein steers. Journal of Animal Science 87, 4101-4108. doi:10.2527/jas.2009-1959

Silva RR (2011) Respirometria e determinação das exigências de energia e produção de metano de fêmeas bovinas leiteiras de diferentes genótipos. DSc. tese, Universidade Federal de Minas Gerais, MG, Brazil.

Silva DJ, Queiroz AC (2006) 'Análise de alimentos (métodos químicos e biológicos).' 4th edn. (Universidade Federal de Viçosa: Viçosa, MG, Brazil)

Sniffen CJ, O'Connor JD, Van Soest PJ, Fox DG, Russell JB (1992) A net carbohydrate and protein system for evaluating cattle diets: II. Carbohydrate and protein availability. Journal of Animal Science 70, 3562-3577.

Valente TNP, Detmann E, Valadares Filho SC, Queiroz AC, Sampaio CB, Gomes DI (2011) Avaliação dos teores de fibra em detergente neutro em forragens, concentrados e fezes bovinas moídas em diferentes tamanhos e em sacos de diferentes tecidos. Revista Brasileira de Zootecnia 40, 1148-1154. doi:10.1590/S1516-35982011000500029

Van Soest PJ, Robertson JB, Lewis BA (1991) Methods for dietary fiber and non-starch polysaccharides in relation to animal nutrition. Journal of Dairy Science 74, 3583-3597. doi:10.3168/jds.S0022-0302 (91)78551-2 